\title{
A social cognition perspective on entrepreneurial personality traits and intentions to start a business: Does creativity matter?
}

\author{
Journal: Management Decision \\ Manuscript ID MD-12-2020-1592.R3 \\ Manuscript Type: Original Article \\ artistic creativity, scholarly creativity, entrepreneurial personality traits, \\ Keywords: entrepreneurial intention, nascent entrepreneurs, Social Cognition \\ Theory \\ Authors: Levent Altinay \\ Endrit Kromidha \\ Armiyash Nurmagambetova \\ Zaid Alrawadieh \\ Gulsevim Kinali Madanoglu
}




\section{ABSTRACT:}

This paper proposes and empirically assesses a social cognition conceptual model linking creativity (both artistic and scholarly), entrepreneurial personality traits, and entrepreneurial intention. Specifically, the study draws on social cognition perspectives to investigate the potential role of creativity as a mechanism underlying the relationship between entrepreneurial personality traits and entrepreneurial intention.

Using a sample of 194 creative nascent entrepreneurs, the study tests the proposed model using Partial Last Squares Structural Equations Modeling (PLS-SEM).

The study reveals that, among entrepreneurial personality traits, only risk-taking propensity is positively related to entrepreneurial intention. Interestingly, while artistic creativity seems to enhance entrepreneurial intention, scholarly creativity is found to stimulate a more cautious approach toward venturing. The findings also reveal that scholarly creativity fully mediates the relationship between tolerance for ambiguity and entrepreneurial intention.

CUST_RESEARCH_LIMITATIONS/IMPLICATIONS_(LIMIT_100_WORDS) :No data available.

CUST_PRACTICAL_IMPLICATIONS_(LIMIT_100_WORDS) :No data available.

CUST_SOCIAL_IMPLICATIONS_(LIMIT_100_WORDS) :No data available.

The study makes an original contribution by showcasing how both artistic and scholarly creativity developed in the same socially situated cognitive environment can differentially influence decisionmaking and the relationship between entrepreneurial personality traits and entrepreneurial intention, thus contributing to social cognition perspectives and research in entrepreneurship. 


\title{
A social cognition perspective on entrepreneurial personality traits and intentions to start a business: Does creativity matter?
}

\begin{abstract}
Purpose - This paper proposes and empirically assesses a social cognition conceptual model linking creativity (both artistic and scholarly), entrepreneurial personality traits, and entrepreneurial intention. Specifically, the study draws on social cognition perspectives to investigate the potential role of creativity as a mechanism underlying the relationship between entrepreneurial personality traits and entrepreneurial intention.
\end{abstract}

Design/methodology/approach - Using a sample of 194 creative nascent entrepreneurs, the study tests the proposed model using Partial Last Squares Structural Equations Modeling (PLSSEM).

Findings - The study reveals that, among entrepreneurial personality traits, only risk-taking propensity is positively related to entrepreneurial intention. Interestingly, while artistic creativity seems to enhance entrepreneurial intention, scholarly creativity is found to stimulate a more cautious approach toward venturing. The findings also reveal that scholarly creativity fully mediates the relationship between tolerance for ambiguity and entrepreneurial intention.

Originality/value - The study makes an original contribution by showcasing how both artistic and scholarly creativity developed in the same socially situated cognitive environment can differentially influence decision-making and the relationship between entrepreneurial personality traits and entrepreneurial intention, thus contributing to social cognition perspectives and research in entrepreneurship.

Keywords artistic creativity, scholarly creativity, entrepreneurial personality traits, entrepreneurial intention, nascent entrepreneurs, Social Cognition Theory

Paper type Research paper 


\section{Introduction}

Recent entrepreneurship research has identified the need for theory-based and processoriented approaches to entrepreneurial intention (Bogatyreva et al., 2019; Botsaris and Vamvaka, 2016). Much of the debate about what is considered to be "entrepreneurial activity" is a result of intentionally planned behavior (Krueger and Carsrud, 1993; McMullen and Shepherd, 2006; Van Gelderen et al., 2015). Conceptualized as a propensity to plan and develop new business ideas (Liñán and Fayolle, 2015), entrepreneurial intention has received considerable attention in mainstream entrepreneurship research. A considerable body of literature suggests that individuals with specific personality traits such as propensity for risktaking, tolerance for ambiguity, and innovativeness are more likely to start a business (Thomas and Mueller, 2001; Esfandiar et al., 2019, 2021). While a steady stream of studies establishes that personality traits have a direct effect on entrepreneurial intention, there is less emphasis on how abilities such as creativity influence the intention to start a business (Biraglia and Kadile, 2017). Hence, there is a need to consider not only the direct effect of creativity but also its mediating role as a potential mechanism underlying the relationship between entrepreneurial personality traits and entrepreneurial intention.

Creativity has generally been viewed as a major component of entrepreneurship, as entrepreneurs need to be able to recognize opportunities, generate ideas, and innovate (Zhao et al., 2018). Furthermore, creativity has been suggested as an antecedent of entrepreneurial intention (Biraglia and Kadile, 2017; Kumar and Shukla, 2019). Cognitive approaches to entrepreneurship focus on a person's creativity as a vital, yet under-explored antecedent of entrepreneurial intention (Esfandiar et al., 2019; Ward, 2004). This is surprising because the success of new ventures is often linked to differentiation and value creation emanating from an individual's capacity to be innovative and creative (Arici and Uysal, 2021; Stauffer, 2016). According to Morris and Kuratko (2002), creativity is the soul of entrepreneurship because it requires entrepreneurs to identify the patterns and trends that define opportunities. Despite its importance for business creation (Biraglia and Kadile, 2017), creativity has received scant attention in entrepreneurship research. Very little is known about how different domains of creativity - specifically artistic creativity and scholarly activity -can directly influence entrepreneurial intention and mediate the relationships between entrepreneurial personality traits and entrepreneurial intention. It is important to understand the mechanism(s) underlying the relationship between entrepreneurial personality traits and intention to start a business because this shows how entrepreneurial traits influence creative abilities which, in turn, 
increases one's intention to start up a business. To address these shortcomings in the literature, this study investigates both the direct and indirect effects of entrepreneurial personality traits and entrepreneurial intention. In addition, we look at the direct and mediating effect of two domains of creativity - artistic and scholarly.

This study makes the following contributions. First, it jointly considers entrepreneurial personality traits and creativity as antecedents of entrepreneurial intentions, which provides a more integrated look into determinants of entrepreneurial intention. Importantly, unlike previous studies on creativity and entrepreneurial intention (Biraglia and Kadile, 2017; Zampetakis and Moustakis, 2006) which employ creativity as a unidimensional construct, this study encompasses two distinct domains of creativity (i.e. artistic and scholarly). By doing so, the present study extends the traits-abilities-intentions framework (Zampetakis et al., 2009) that has rarely been tested in the entrepreneurship research. While personality traits have been used as determinants of entrepreneurial intention in numerous studies, abilities such as creativity have seldom been jointly included in such models.

Second, the study extends entrepreneurial intentions literature by considering a social cognition perspective which is different from the commonly used theory of planned behavior (Ajzen, 1991) and the entrepreneurial event model (Shapero and Sokol, 1982) proposed as alternatives to entrepreneurial personality perspectives. The social cognition perspective in this study is based on Social Cognition Theory (Bandura, 1986) and socially situated cognition views (Mitchell, Randolph-Seng, and Mitchell, 2011; Smith and Semin, 2004) to study entrepreneurial intention in context. Based on the tenets of a social cognitive perspective, creativity can enable individuals to interpret environmental cues to engage in entrepreneurial behavior (Biraglia and Kadile, 2017; Ko and Butler, 2007). This responds to calls for more research on cognitive, motivational, and emotional forces in various entrepreneurial contexts (Mitchell et al., 2011).

Third, we answer the calls of Carsrud and Brännback (2011) and Schlaegel and Koening (2014) who recommend that studies should go beyond direct effects of antecedents of the intention to start a business and employ potential mediators. We attend to this call by considering the mediating mechanism of creativity on the relationship between entrepreneurial personality traits and entrepreneurial intention. More specifically, the study expands on the concept of creativity in entrepreneurship by modeling two key creativity domains - artistic creativity and scholarly creativity. This is an important area of inquiry not only theoretically but also practically since creativity is not only a prerequisite for entrepreneurship but also an 
integral part of the inner workings of entrepreneurship processes. In sum, this study advances our understanding of decision-making processes in creative entrepreneurship and offers several implications for policy makers.

\section{Literature review}

\section{Entrepreneurial personality traits and entrepreneurial intention}

The personality approach has been a widely adopted lens in understanding entrepreneurship. Broadly speaking, this approach suggests that personality traits are what set entrepreneurs apart from non-entrepreneurs (Kerr et al., 2018). Previous research identifies a high need for achievement, internal locus of control, risk-taking orientation, high tolerance of ambiguity, high degree of self-confidence, and innovativeness as the key entrepreneurial personality traits (Esfandiar et al., 2019; Kerr et al., 2018; Rauch, Wiklund et al., 2009; Wales et al., 2013). These traits are not only important to understand entrepreneurial intention but also tend to predict business performance (Karami and Tang, 2019; Palmer et al., 2019). Studies opposing the entrepreneurial personality traits approach focus on how organizations emerge and instead propose a focus on a behavioral approach (Gartner, 1989), which led to adapting a more critical approach to how entrepreneurial intention is linked to personality traits (Altinay et al., 2012; Krueger and Carsrud, 1993).

A well-established body of literature views entrepreneurial personality traits as inherent to the nature of the entrepreneurs. In this vein, entrepreneurial personality traits can be significant factors in encouraging intentions to venture. Entrepreneurial intention is "a process, state, or act of conscious willing" (Bird, 2015, p.143) involving commitment to perform the behaviors necessary for creating a new venture (Krueger and Carsrud, 2000). The crucial importance of entrepreneurial intention stems from the widely accepted notion contending that intentions can be the best predictors of behavior (Ajzen, 2011; Kautonen et al., 2015). A metaanalysis of 98 studies (Schlaegel and Koenig, 2014) reported that the theory of planned behavior (Ajzen, 1991) and the entrepreneurial event model (Shapero and Sokol, 1982) are the two most prominent theories employed to explain entrepreneurial intention. The former theory includes attitudes toward the behavior, subjective norms, and perceived behavioral control, while the latter consists of perceived desirability, propensity to act, and perceived feasibility as determinants of entrepreneurial intention. More recently, in the context of entrepreneurship, several recent studies explain the action-intention nexus by employing various psychological 
and contextual variables (Esfandiar et al., 2019; Van Gelderen et al., 2015) such as personal abilities and environmental factors.

In this study, we use tolerance for ambiguity, risk-taking propensity, and innovativeness as three entrepreneurial personality traits which act as antecedents of entrepreneurial intention. These are aligned with the original three-dimension model of entrepreneurial orientation scale consisting of innovativeness, proactiveness, and risk-taking (Rauch et al., 2009; Wales et al., 2013). However, as noted above, the role of creative behavior as an ability needs to be considered concurrently so that a full-fledged psychology-rooted approach is adopted. Moreover, existing research addressing entrepreneurial intention seems to neglect nascent entrepreneurs. For instance, Bird (2015) reviewed 78 articles focusing on entrepreneurial intention and noted that more than $80 \%$ of them focused on the entrepreneurial intention of students, which suggests that most of them may not even be in the early stages of entrepreneurship such as ideation. Conversely, the current study focuses on entrepreneurial intentions of nascent entrepreneurs, who may be in the early planning stages of venture creation, to understand the relationship between entrepreneurial personality traits and entrepreneurial intention by examining the underlying mechanism of creativity.

\section{Creativity as an enabler of entrepreneurship and innovation}

Simply defined as "showing imagination and originality of thought in moving beyond everyday thinking" (Fillis and Rentschler 2010, p. 51), creativity is widely recognized as a key antecedent of entrepreneurship (Biraglia and Kadile, 2017; Kumar and Shukla, 2019). Creativity (i.e. generating novel ideas) is also crucial to achieving innovation (i.e. implementation of ideas) (Ahlin et al., 2014; Anderson et al., 2014). However, despite its importance as a stimulus of business venturing, creativity has not received much coverage in the mainstream entrepreneurship literature (Nielsen and Stovang, 2015). Although important across different stages of entrepreneurship, creativity may be particularly important for nascent ventures since creative ideas generate economic value resulting in useful ways of operating (Belitski et al., 2019). Ideas that "lie outside the purview of dominant ways of thinking" lead to superior performance because they are less challenged, rarer, and trickier to copy than easily discovered ideas (Gavetti, 2012, p. 267).

Measuring creativity is a challenging task because there are five types of measures of that construct; these are creative behavior, creative personality, divergence thinking test, remote associate test, and creative product test (Xu et al., 2019). Among these measures, 
creative behavior emerges as particularly relevant in the context of entrepreneurship and is a multi-domain concept that comprises five domains of creativity; these are self/everyday, scholarly, performance (encompassing writing and music), mechanical/scientific, and artistic (Kaufman, 2012). Among these, artistic creativity and scholarly creativity can be two useful domains to understand the interface between creativity and entrepreneurial intention. Artistic creativity is conceived as the cognitive set of skills and abilities that can influence entrepreneurship (Ward, 2004). From this perspective, the entrepreneur may be viewed as an artist whose creative skills, abilities, and knowledge serve to trigger entrepreneurial intention (Camacho-Miñano and del Campo, 2017). Artistically creative entrepreneurs are described as more sensitive toward the arts and creative processes (Chen and Tseng, 2021). They are also open to unique and fresh ideas and possess the artistic capacity necessary to support their venturing endeavors (Zhao et al., 2018). Unlike artistic creativity, scholarly creativity refers to the intellectual ability of individuals and involves creative analysis, debate, and scholarly pursuits (Kaufman, 2012). This intellectual readiness can often be enhanced by specific entrepreneurial training thus serving as a potential stimulus encouraging entrepreneurial intention (Lautenschläger and Haase, 2011). Based on these explanations, in the context of entrepreneurship, both artistic and scholarly forms of creativity can be viewed as abilities that operate on the premise of social cognition.

\section{A social cognition perspective on entrepreneurship and creativity}

According to SCT (Bandura, 1986), creativity can be considered a cognitive competence which enables individuals to interpret environmental cues in context and respond accordingly (Biraglia and Kadile, 2017; Ko and Butler, 2007). Entrepreneurially inclined individuals consider factors that emerge in the environment, and these very same factors can be combined with personal abilities such as creativity to facilitate entrepreneurial intention (Biraglia and Kadile, 2017). Artistic and scholarly forms of creativity are particularly important for nascent entrepreneurs who are in the early stages of setting up a business; hence, these creative abilities can help individuals solve complex situations in the process of starting up a venture. In the context of entrepreneurship and creativity, although the latter is useful in generating new ideas and opportunities, the cognitive and knowledge processes behind it can, paradoxically, enhance or inhibit creativity (Ward, 2004). In the general social context of this study, artistic creativity can be related to the socio-cultural context as research comparing Chinese and American students shows (Niu and Sternberg, 2001). Scholarly creativity, on the other hand, is more related to specific needs and innovation rather than to adaptation in a 
specific context (Wang, Chen, Zhang, and Deng, 2017). Clearly cognition, creativity and entrepreneurship are inextricably related (Ward, 2004) and some research suggests looking at entrepreneurial teams (Shepherd and Krueger, 2002) or peers (Bellò, Mattana, and Loi, 2018) to understand how entrepreneurial intentions and outcomes are shaped in the social context of creativity. However, entrepreneurship research in this direction remains limited for us to fully understand the relationship between cognition, creativity, and entrepreneurial intention.

A more recent socially situated cognition perspective suggests that social objects are not only the canvas where activities happen, but they actively shape our behavior (Smith and Semin, 2004) whereby cognition is action-oriented, embodied, situated and distributed (Mitchell et al., 2011). This presents an alternative to the entrepreneurial personality perspective, highlighting relationships, experiences, and interactions between people (Mitchell et al., 2002). Clarke and Cornelissen (2011) operationalized cognition in entrepreneurship by locating it in the context of language and sense-making. More recent studies expand the social cognition perspective in the context of cross-country entrepreneurial activity (Raza, Muffatto, and Saeed, 2018) or networks (Thomas, Randolph, and Marin, 2019) where relationships are complex and extend beyond organizational and cultural boundaries. These studies confirm that a social cognition perspective in entrepreneurship creates opportunities to combine cognitive, motivational, and emotional forces in various social contexts (Mitchell et al., 2011).

We contend that adopting a social cognition perspective to explain entrepreneurial intention offers a more holistic picture of how traits, abilities, and the social context are reciprocal in facilitating entrepreneurial intention. Unlike the entrepreneurial event model that hinges on aspects such as desirability and feasibility, which can be considered "pull" factors that attract individuals to entrepreneurship, social cognition can help explain the role of creativity and entrepreneurial intention based on "push" factors where artistic and scholarly creativity can become internal motivators of entrepreneurial action.

\section{Conceptual framework and hypotheses}

\section{Tolerance for ambiguity and entrepreneurial intention}

Tolerance for ambiguity refers to individuals' ability to cope with and accept uncertainty, unpredictability, and conflicting directions (Acedo and Jones, 2007; Peschl et al., 2021). Entrepreneurs normally make decisions with relatively scant information and take time to create a venture with little prospect of success (Shepherd et al., 2015). There are high levels 
of uncertainty when developing a new venture with high risk of failure during the early phases of venturing (Zhang et al., 2020). Therefore, entrepreneurs are required to cope with high degrees of uncertainty on a regular basis. Tolerance for ambiguity is seen as vital for entrepreneurship given its role in determining entrepreneurial intent and success (McMullen and Shepherd, 2006). It is believed that entrepreneurs thrive in the presence of ambiguity since that provides the space for realizing opportunities (Krueger et al., 2000). This means that entrepreneurs must often make decisions with limited information, thus risking uncertain outcomes (Altinay et al., 2012). This requires a high level of tolerance for ambiguity which is considered important for entrepreneurship (McMullen and Shepherd, 2006). Yet, empirical findings on the relationship between tolerance for ambiguity and entrepreneurial intention are not conclusive with some studies confirming a positive relationship (Che Embi et al., 2019; Ehsanfar et al., 2021) and others failing to do so (Dinis et al., 2013; Gurel et al., 2010). Hence, there seems to be a need for more empirical investigation into this relationship. Based on the preceding discussion, we propose the following hypothesis:

H1: There is a positive relationship between tolerance for ambiguity and entrepreneurial intention.

\section{Innovativeness and entrepreneurial intention}

Entrepreneurship is often associated with innovation (Galindo-Martín et al., 2020). As the fruit of creativity (Ahlin et al., 2014; Anderson et al., 2014), innovativeness has gained considerable attention in entrepreneurship research as it is considered as one of the distinctive entrepreneurial traits (Armstrong and Hird, 2009). The positive relationship between innovativeness and entrepreneurial intention is also confirmed across various industries and fields of business (Altinay et al., 2012; Dutta et al., 2015; Gurel et al., 2010). According to the adaptation-innovation theory, entrepreneurs are more innovative than non-entrepreneurs (Gurol and Atsan, 2006). As noted by Thomas and Mueller (2000, p. 296), "in every definition of entrepreneurship, innovation is inevitably a core component". As an antecedent of entrepreneurship, innovation is so important that Schumpeter (2000) considers an entrepreneur as an innovator. Findings from previous research (e.g., Altinay et al., 2012; Gurol and Atsan, 2006; Nasip et al., 2017) indicate that innovativeness is positively related to entrepreneurial intention. For instance, Gurel et al. (2010) found a positive and significant relationship between innovativeness and entrepreneurial intention across two samples from Turkey and the UK. We therefore propose the following hypothesis: 
H2: There is a positive relationship between innovativeness and entrepreneurial intention.

\section{Risk-taking propensity and entrepreneurial intention}

As a key entrepreneurial trait, risk-taking propensity refers to the degree to which individuals are willing to accept the consequences of failure when they take risks compared to the opportunity of receiving rewards (Altinay et al., 2012; Gurol and Atsan, 2006). Hisrich et al. (2005) explained that, to create something new and valuable, entrepreneurs need to assume the accompanying financial, psychological and social risk before realizing subsequent rewards. Previous research (see Esfandiar et al., 2019) investigating the relationship between risk taking propensity and entrepreneurial intention found a positive relationship between risk taking and venture creation. Risk-taking propensity seems to be a common characteristic of entrepreneurs. Overall, there is considerable empirical evidence to support the notion that individuals who have greater propensity to rake risks are more likely to be entrepreneurial (Farrukh et al., 2018; Lopez-Nunez et al., 2020). Che Embi et al. (2019) and more recently, Ehsanfar et al. (2021) confirmed the positive association between risk-taking propensity and entrepreneurial intention. We have therefore formulated the following hypothesis:

H3: There is a positive relationship between propensity to take risks and entrepreneurial intention.

\section{Artistic creativity and entrepreneurial intention}

As discussed earlier, creativity plays a crucial role in shaping entrepreneurial intentions (Kumar and Shukla, 2019) and is acknowledged as a key antecedent of innovation (Anderson et al., 2014). As one domain of creativity, artistic creativity can stimulate entrepreneurial intention given that individuals with greater artistic creativity are often open to engaging in new experiences (Chen and Tseng, 2021). Individuals who enjoy artistic creativity are more prone to use their creative skills, abilities, and knowledge as a stimulus for entrepreneurial action (Camacho-Miñano and del Campo, 2017). Overall, entrepreneurs need to exhibit high levels of creativity since it contributes to the design of new products and services (Gielnik et al., 2012). Although limited, there exists some empirical evidence alluding to the role of artistic creativity in enhancing entrepreneurial intention. For instance, Zampetakis et al. (2011) suggested that individuals with more observed creativity and - by extension - artistic creativity are more likely to build their own businesses. Likewise, Zhao et al. (2018) found that artistic 
creativity was a key focus for their sample of respondents' intention to create new businesses. Therefore, we hypothesize that:

H4: There is a positive relationship between artistic creativity and entrepreneurial intention to start a business.

\section{Scholarly creativity and entrepreneurial intention}

Like those with artistic creativity, individuals with scholarly creativity are also likely to possess intellectual assets that enable creative analysis and generation of useful and creative ideas (Hu et al., 2018; Kaufman, 2012). These intellectual assets may well serve to encourage venturing (Hamidi et al., 2008). Creativity enables individuals to recognize opportunities and prospects for new ideas and enhances efficient use of both existing and novel approaches (Ahlin et al., 2014). Scholastic creativity in entrepreneurship can be generally cultivated through training (Sun et al., 2017). According to Hu et al. (2018), entrepreneurship education should focus on promoting positive personal traits including creativity. The transferable skills and knowledge gained through these training opportunities enable individuals to create economic value because of more efficient operating (Belitski et al., 2019). Prospective entrepreneurs who are scholarly creative are usually less constrained by conventional thinking and thus less likely to act on ideas that are easily discovered (Gavetti, 2012). Scholarly creativity may also help prospective entrepreneurs feel confident about their decisions to start a business. Thus, one may argue that the higher the level of scholarly creativity in people, the higher their entrepreneurial intentions are. Based on this, the above discussion frames the following hypothesis:

H5: There is a positive relationship between scholarly creativity and entrepreneurial intention to start a business.

\section{The mediating effects of creativity}

While there exists a plethora of research exploring the relationships between entrepreneurial personality traits and entrepreneurial intention, it is unclear how creativity serves as a potential mechanism to underpin these relationships. Previous research examines the mediating effects of entrepreneurial self-efficacy (Samydevan et al., 2020), entrepreneurial alertness (Hu et al., 2018), and attitude toward entrepreneurship (Farrukh et al., 2018) on the relationships between entrepreneurial personality traits and entrepreneurial intention. Creativity has also been employed as a mediator variable in some studies (e.g., Danish et al., 
2019). Yet, to the best of the authors' knowledge, no study has examined how different domains of creativity - specifically artistic creativity and scholarly activity - can explain the relationships between entrepreneurial personality traits and entrepreneurial intention. It is important to investigate the mechanism underpinning the interface between different entrepreneurial personality traits and intention to start a business given the scarcity of research that encompasses traits and creative abilities in the same model (Zampetakis et al., 2009). This lack of research on the joint influence of traits and creative abilities raises the need for a nuanced understanding of the mechanism underlying the relationship between entrepreneurial personality traits and intention to start a business. Moreover, despite the fact that creativity is often cited as a crucial component in entrepreneurship (Kumar and Shukla, 2019), creative behavior has been largely overlooked in the entrepreneurship literature (for some notable exceptions see Biraglia and Kadile, 2017 and Danish et al., 2019).

While there are no specific studies in entrepreneurship that link entrepreneurial personality traits and creativity, one can surmise that individuals who possess high levels of tolerance for ambiguity, innovativeness, and risk-taking propensity should be able to demonstrate artistic creativity and scholarly activity abilities. For example, a person who is accustomed to handling ambiguous situations and has a risk-taking personality should be more open to fresh, new ideas that foster his or her artistic capacity (Zhao et al., 2018), which in turn would lead to a higher probability to engage in entrepreneurship. By the same token, individuals with high tolerance for ambiguity, innovativeness, and risk-taking propensity would possess inquisitive minds that have high intellectual ability to analyze situations and decipher signals in the environment that offer opportunities to launch their own business. In other words, personality traits can offer a boost to one's artistic and scholarly creativity which, in essence, enables entrepreneurial minds to act as parachutes that are full of air and sail smoothly toward their target (i.e. launching a venture). Another metaphor to help explain the mediating role of creativity is the one of a bowling alley. In a bowling alley, there comes a push from the entrepreneurial personality (the bowling ball) and creative behavior acts as the alley (lane) to help achieve the objective of knocking down pins (i.e. start up a business). While the bowling ball can strike the pins without using the alley, the alley provides a more smooth and focused approach to knock down the pins. Based on the above discussions, the following hypotheses are formulated:

H6a There is a positive indirect relationship between tolerance for ambiguity and entrepreneurial intention mediated by artistic creativity. 
H6b There is a positive indirect relationship between tolerance for ambiguity and entrepreneurial intention mediated by scholarly creativity.

H7a There is a positive indirect relationship between innovativeness and entrepreneurial intention mediated by artistic creativity.

H7b There is a positive indirect relationship between innovativeness and entrepreneurial intention mediated by scholarly creativity.

H8a: There is a positive indirect relationship between propensity to take risks and entrepreneurial intention mediated by artistic creativity.

H8b: There is a positive indirect relationship between propensity to take risks and entrepreneurial intention mediated by scholarly creativity.

\section{INSERT FIGURE 1 HERE}

\section{Methodology}

\section{Sampling and data collection}

The data for the present study were collected from potential young creative entrepreneurs who were seeking consultation about how to start a business and/or taking some business start-up courses in a business development center in Kazakhstan. Their main areas of activity were design, information technology, and architecture. We utilized convenience sampling because potential entrepreneurs were readily available at the small business development center. We administered an in-person questionnaire that was filled out on computers available at the center. The initial sample consisted of 224 respondents. The purpose of the study was to assess entrepreneurial intention among nascent entrepreneurs. Therefore, the qualifying question for inclusion in this study was: "After this course, do you have any intention or plan to start your own business?" Only participants that responded "Yes" (N=194) to this question remained in the final sample. To address potential sample selection bias, and to consider the equivalency of responding "No" $(\mathrm{N}=30)$ to entrepreneurial intention question and responding "Yes" but assigning $0 \%$ probability to start a business $(\mathrm{N}=9)$, analysis was repeated along with robustness checks via bootstrapping. Findings indicate that there was no material change to our main findings as the significant coefficients remained at identical levels. Prior to its administration the questionnaire was first translated into Kazakh language and then 
back-translated into English by two independent experts to ensure that the statements were correctly understood by participants.

\section{Measures}

Entrepreneurial intention is employed as the outcome variable in the proposed model. Entrepreneurial intention is operationalized as either a binary variable (yes/no) (Krueger and Carsrud, 1993) or as a continuum that is based on probability (van Gelderen et al., 2008). We took the latter view indicating that entrepreneurial intention was a probability that ranges between $0 \%$ and $100 \%$. In the questionnaire, entrepreneurial intention was measured by a single indicator adapted from van Gelderen et al. (2008). Respondents were asked the following question: "How likely do you consider it to be that within five years from now you'll be running your own firm?" and answers were distributed in quartiles where 1 would equal $25 \%$ and 4 would denote $100 \%$.

The remaining constructs were measured using multiple-item scales adopted from previous research. Tolerance for ambiguity was measured using four items adapted from Acedo and Jones (2007). Risk-taking propensity was operationalized using 10 items adapted from the Jackson Personality Inventory (Jackson, 1994). Eight items from Mueller and Thomas (2001) based on the Jackson Personality Inventory (Jackson, 1994) were also used to measure innovativeness. Respondents were asked to indicate their level of agreement with each item on a 5-point Likert scale ranging from [1] = strongly disagree to [5] = strongly agree.

Creativity was measured using the Kaufman Domains of Creativity Scale (K-Docs) (Kaufman, 2012). While the scale includes five domains, only artistic creativity and scholarly creativity were included in the present study as these two domains are clearly distinguished from each other and broad enough to suit the diverse entrepreneurship context. Respondents were asked the following question: "Compared to people of approximately your age and life experience, how creative would you rate yourself for each of the following acts? For acts that you have not specifically done, estimate your creative potential based on your performance on similar tasks." The items were measured on a 5-point Likert scale, with [1] = being much less creative and $[5]=$ being much more creative. 


\section{Data analysis}

For the estimation of the proposed model, Partial Last Squares (PLS) Structural Equations Modeling (SEM) was used (Hair et al., 2017). A key advantage of PLS-SEM is that it achieves good levels of statistical power even with smaller sample sizes as is the case in this study $(\mathrm{n}=194)$. PLS-SEM is conducted through a two-step process including the assessment of the measurement model (outer model) and the assessment of the structural model (inner model). The model was assessed using Smart PLS 3.0 and the results were bootstrapped $(\mathrm{n}=$ 5000). Commonly accepted threshold values for both models (measurement and structural) are reported in the findings section.

\section{Results}

\section{Measurement model}

Before assessing the proposed structural model, the measurement model was assessed by examining internal consistency, convergent validity, and discriminant validity. After dropping one item from the innovativeness scale due to low factor loading, all Cronbach's alpha and composite reliability scores were above the recommended 0.7 (Hair et al., 2017). Convergent validity was assessed using the average variance extracted (AVE) for each construct. Given that all scores were above the recommended 0.5 (Hair et al., 2017), convergent validity was established (see Table 1).

\section{INSERT TABLE 1 HERE}

Discriminant validity was assessed by employing Heterotrait-Monotrait Ratio of Correlations (HTMT). HTMT values for all construct pairs were well below the acceptable threshold of 0.90 indicating satisfactory discriminant validity for all constructs used in the model (Hair et al., 2017). Among the residual measures, the standardized root mean square residual (SRMR) had an acceptable fit of 0.053. Likewise, the normed fit index (NFI) was 0.959 which exceeds the threshold of 0.95 (Hair et al., 2017).

\section{INSERT TABLE 2 HERE}




\section{Structural model}

Results of the structural model are presented in Figure 2 and Table 3. Jointly, personality traits explain $13.8 \%$ of the variance in artistic creativity and $25.8 \%$ of the variance in scholarly creativity. Personality traits and creativity measures account for the $11.1 \%$ of variance in entrepreneurial intention. Findings show that there is a significant and positive relationship between tolerance for ambiguity and scholarly creativity $(\beta=0.289, \mathrm{p} \leq 0.001)$ whereas tolerance for ambiguity has no effect on artistic creativity $(\beta=-0.139, p>0.05)$. H1 predicted that tolerance for ambiguity is positively related to entrepreneurial intention. Results indicate that this relationship is not significant $(\beta=0.077, \mathrm{p}>0.05)$; hence $\mathrm{H} 1$ is not supported. Innovativeness is positively related both to scholarly creativity $(\beta=0.252, p \leq 0.01)$ and artistic creativity $(\beta=0.424, p \leq 0.001)$. As can be seen in Table 3 , innovativeness is not significantly related to entrepreneurial intention $(\beta=-.029, \mathrm{p}>0.05)$, and thus $\mathrm{H} 2$ is not supported. Risktaking propensity has a significant relationship with scholarly creativity $(\beta=0.364, p \leq 0.001)$ but it is not significantly related to artistic creativity $(\beta=-.086, p>0.05)$. Analysis also reveals that risk-taking propensity is positively related to entrepreneurial intention $(\beta=0.395, p \leq 0.001)$, which lends support to $\mathrm{H} 3$. That is, individuals who possess higher risk-taking propensity are more likely to start a business. Results also support H4, indicating that individuals with high artistic creativity are more likely to start their own business $(\beta=0.197, \mathrm{p} \leq 0.05)$. However, contrary to the predictions of $\mathrm{H} 5$, scholarly creativity has a negative relationship with entrepreneurial intention $(\beta=-0.227, \mathrm{p} \leq 0.01)$. In other words, individuals with high scholarly creativity are less likely to engage in entrepreneurship.

\section{INSERT FIGURE 3 HERE}

\section{INSERT TABLE 3 HERE}

Finally, the study examines the mediating effects of creativity - both artistic and scholarly - on the relationship between entrepreneurial personality traits and entrepreneurial intention. The mediating effects were assessed following the suggestions of Zhao et al. (2010) whereby even in cases of a non-significant relationship between two variables, one can still assess an indirect effect via the mediator. As presented in Table 4, findings indicate that only tolerance for ambiguity has a positive indirect effect on entrepreneurial intention through scholarly creativity $(\beta=0.065, \mathrm{p}<0.05)$, thus lending support to H6b. Contrary to predictions, though, our results fail to support the remaining indirect paths for the other personality traits. 


\section{Discussions, implications, and conclusion}

The present study has proposed and empirically assessed a conceptual model linking creativity, entrepreneurial personality traits, and entrepreneurial intention by adapting a social cognition perspective (Bandura 1986; Mitchell at al., 2011; Smith and Semin, 2004). In particular, the study has explored creativity (both artistic and scholarly) as a potential mechanism underpinning the relationships between entrepreneurial personality traits and entrepreneurial intention. The proposed framework was assessed using data collected from potential nascent entrepreneurs in Kazakhstan. Findings from the present study have significant theoretical and practical implications.

In line with previous studies (Altinay et al., 2012; Che Embi et al., 2019; Ehsanfar et al., 2021; Gurol and Atsan, 2006; Gurel et al., 2010; Lopez-Nunez et al., 2020), entrepreneurs with high propensity to take risks are more likely to engage in entrepreneurial activity. However, contrary to past studies (Che Embi et al., 2019; Ehsanfar et al., 2021), our findings fail to confirm the positive effect of tolerance for ambiguity on entrepreneurial intention adding more empirical support to the findings reported in previous research which show that some traits are not significantly related to intentions (e.g., Dinis et al., 2013). Likewise, our findings fail to confirm the positive effect of innovativeness on entrepreneurial intention.

The study's results also show that artistic creativity can enhance entrepreneurial intention, thus supporting scarce evidence alluding to the positive effect of artistic creativity on entrepreneurial intention (Zampetakis et al., 2011; Zhao et al., 2018). Unlike artistic creativity, scholarly creativity is negatively associated with entrepreneurial intention. This finding is interesting and inconsistent with existing theorizing (Hu et al. (2018; Lautenschläger and Haase, 2011). While this finding should encourage further investigation, one may argue that individuals who exhibit high scholarly creativity may demonstrate a more cautious approach to business creation. In other words, scholarly creativity may be associated with a more calculated decision-making process whereby individuals approach the idea of creating a new business with a stringent evaluation of the potential costs and benefits. Another potential explanation of the negative effect of scholarly creativity on entrepreneurial intention may be related to the operationalization of the construct itself. As one domain of creativity, items measuring scholarly creativity focus on the intellectual ability of individuals including creative analysis and scholarly pursuits (Kaufman, 2012). These intellectual abilities may direct individuals towards paths other than entrepreneurship (e.g., academic career). 
Our findings fail to confirm the major number of hypotheses related to the proposed mediating role of creativity on the relationship between entrepreneurial personality traits and entrepreneurial intention. Interestingly, however, scholarly creativity appears to fully mediate the relationship between tolerance for ambiguity and entrepreneurial intention. Artistic creativity can also emerge as a viable mediator between innovativeness and entrepreneurial intention. Indeed, in the present study, the indirect effect of innovativeness on entrepreneurial intention through artistic creativity was very close to the .05 level of statistical significance (see Table 4). This should also encourage further investigation with larger samples.

This study makes three specific contributions to the existing body of knowledge. First, it adds more empirical support to the inconclusive findings reported in previous research focusing on the relationship between entrepreneurial personality traits and entrepreneurial intention (Che Embi et al., 2019; Dinis et al., 2013; Ehsanfar et al., 2021; Ferreira et al., 2012; Gurel et al., 2010). In doing so, the study responds to the research call for combining cognitive, motivational, and emotional forces in various social contexts (Mitchell et al., 2011). Unlike previous studies that draw on data from students, this research uses data from nascent entrepreneurs, thus providing a more nuanced understanding of the relationship between entrepreneurial personality traits and entrepreneurial intention in the context of cognition and creativity. In practice, this is important for entrepreneurs to make informed decisions by considering both personality traits and social conditions that influence their behavior.

Second, the study advances our understanding of the relationship between entrepreneurial personality traits and intentions to start a business by examining creativity as a potential mechanism underpinning this relationship. Surprisingly, while creativity is acknowledged as a crucial component in entrepreneurship (Biraglia and Kadile, 2017; Kumar and Shukla, 2019), it has rarely been employed as a mediator in the entrepreneurship literature (for an exception see Danish et al., 2019). The present study even goes a step further by drawing on two key and distinct domains of creativity - artistic creativity and scholarly activity - to understand how creativity can help understand the complex relationship between nascent entrepreneurs' personality traits and their intentions to start a business. In practice, entrepreneurs could consider creativity as something they can advance, use, and adapt in their social context for entrepreneurship gains and opportunities rather than as something inherent from their personality and to be taken for granted.

Third, while previous research tends to employ the theory of planned behavior (Ajzen, 1991) and the entrepreneurial event model (Shapero and Sokol, 1982) to understand 
entrepreneurial intentions, our study extends entrepreneurial intentions literature by drawing on social cognition perspectives (Bandura 1986; Mitchell at al., 2011; Smith and Semin, 2004). We used them to establish a theoretical underpinning showcasing how cognitive competencies such as creativity can enable individuals to interpret environmental cues to engage in entrepreneurial behavior (Biraglia and Kadile, 2017; Ko and Butler, 2007). Practically this contribution could inform entrepreneurial strategy and planning by embedding creativity as an important element of translating the environment around the new venture and taking advantage of opportunities within it.

For policy, findings from this study shows how artistic and scholarly forms of creativity play an important role towards entrepreneurial intention by connecting individual personality traits to the social context. This suggests that entrepreneurial support should go beyond business training programs and be better positioned in the social cognitive context of creativity, intentions, and behavior. Our findings show that artistic creativity can enhance entrepreneurial intention. Therefore, individuals who are more sensitive toward arts and are open to unique and fresh ideas are more likely to consider venturing. This can help different stakeholders such as universities offering entrepreneurship education to identify individuals who are likely to venture; and support them accordingly. Indicators of artistic creativity (e.g., appreciation of arts) should also be monitored, particularly in business development centers targeting nascent entrepreneurs. The presence of these indicators will not only help understand the intentionaction nexus but will also facilitate drawing inferences useful to target and focus on individuals who are likely to venture.

Our findings also indicate that scholarly creativity fully mediates the relationship between tolerance for ambiguity and entrepreneurial intention. An obvious implication of this is that governments and other stakeholders should invest in providing training and consultant services to prospective entrepreneurs. In other words, scholarly creativity may serve as an 'encouraging' factor, helping to overcome the fear of uncertainty among prospective entrepreneurs, thus fostering their entrepreneurial intention. This will not only help them tolerate ambiguity and thus foster their entrepreneurial intentions, but it will also help them approach their initial entrepreneurial ideas more realistically, thus reducing failure rates. This assumption is also supported by the negative relationship between scholarly creativity and entrepreneurial intentions.

Finally, while our findings suggest a negative impact of scholarly creativity on entrepreneurial intention, this should not lead us to assume that scholarly creative people are 
less encouraged to start a business; rather, it indicates that they are likely to adopt a more cautious approach toward venturing. This notion, albeit open to discussion and further validation studies, should not lead to underestimating the role of intellectual ability of individuals such as creative analysis, debate, and scholarly pursuits in shaping entrepreneurship intentions.

\section{Limitations and areas of future research}

The study concludes with some limitations that may be worth exploring in future research. First, our model was assessed drawing on a cross-sectional research design and using data from nascent entrepreneurs in an ex-communist developing country. Therefore, the findings may need to be validated drawing on longitudinal study approaches and using data from established entrepreneurs in different contexts. Second, the study focuses on nascent entrepreneurs' future intentions. Future research can follow-up with entrepreneurs' actual actions. This will help explain how the intention-action nexus works thus contributing to a better explanation of the creation of new ventures. Our results largely fail to confirm the mediating role of creativity on the relationship between entrepreneurial personality traits and entrepreneurial intention. This issue may be worth further investigation in diverse contexts and perhaps employing other measures of creativity. Relatedly, and more importantly, our findings show that scholarly creativity is likely to discourage entrepreneurial intentions. While interesting, future research may seek to address this specific relationship before any definitive conclusions can be drawn. 


\section{References}

Acedo, F. J., and Jones, M. V. (2007), "Speed of internationalization and entrepreneurial cognition: Insights and a comparison between international new ventures, exporters and domestic firms". Journal of World Business, Vol. 42 No. 3, pp. 236-252.

Ahlin, B., Drnovšek, M. and Hisrich, R.D. (2014), "Entrepreneurs' creativity and firm innovation: the moderating role of entrepreneurial self-efficacy", Small Business Economics, Vol.43 No. 1, pp. 101-117.

Ajzen, I (2011), "The theory of planned behaviour: Reactions and reflections", Psychology \& Health, Vol. 26 No. 9, pp. 1113-1127.

Ajzen, I. (1991). "The theory of planned behavior," Organizational Behavior and Human Decision Processes, Vol. 50 No. 2, pp. 179-211.

Altinay, L., Madanoglu, M., Daniele, R. and Lashley, C. (2012). "The influence of family tradition and psychological traits on entrepreneurial intention." International Journal of Hospitality Management, Vol. 31 No. 2, pp. 489-499.

Anderson, N., Potočnik, K., and Zhou, J. (2014), "Innovation and creativity in organizations: A state-of-the-science review, prospective commentary, and guiding framework", Journal of Management, Vol. 40 No.5, pp. 1297-1333.

Ang, S.H., and Hong, D.G.P., (2000), "Entrepreneurial spirit among East Asian Chinese", Thunderbird International Business Review, Vol 42 No. 3, pp. 285-309.

Arici, H. E. and Uysal, M. (2021), "Leadership, green innovation, and green creativity: a systematic review", The Service Industries Journal, DOI: 10.1080/02642069.2021.1964482

Armstrong, S. J., and Hird, A. (2009), "Cognitive style and entrepreneurial drive of new and mature business owner-managers", Journal of Business and Psychology, Vol. 24 No. 4, pp. 419-430.

Bandura, A (1986), “The explanatory and predictive scope of self-efficacy theory", Journal of Social and Clinical Psychology, Vol. 4, No 3, pp. 359-373.

Belitski, M., Caiazza, R. and Lehmann, E.E. (2019), "Knowledge frontiers and boundaries in entrepreneurship research", Small Business Economics. https://doi.org/10.1007/s11187019-00187-0

Bellò, B., Mattana, V. and Loi, M. (2018). "The power of peers: A new look at the impact of creativity, social context and self-efficacy on entrepreneurial intentions." International Journal of Entrepreneurial Behavior \& Research, Vol. 24 No. 1, pp. 214-233. 
Biraglia, A. and Kadile, V. (2017), "The role of entrepreneurial passion and creativity in developing entrepreneurial intention: insights from American homebrewers", Journal of Small Business Management, Vol. 55 No. 1, pp. 170-188.

Bird, B. (2015), "Entrepreneurial intention research: A review and outlook", International Review of Entrepreneurship, Vol. 13 No. 3, pp. 143-168.

Bogatyreva, K., Edelman, L. F., Manolova, T.S., Osiyevskyy, O., and Shirokova, G. (2019), "When do entrepreneurial intention lead to actions? The role of national culture", Journal of Business Research, Vol. 96, pp. 309-321.

Botsaris, C., and Vamvaka, V. (2016), “Attitude toward entrepreneurship: Structure, prediction from behavioral beliefs, and relation to entrepreneurial intention", Journal of the Knowledge Economy, Vol. 7 No. 2, pp. 433-460.

Caliendo, M. Fossen, F., Kritikos, A. (2009), "Risk attitudes of nascent entrepreneurs: new evidence from an experimentally-validated survey", Small Business Economics, Vol. 32 No. 2, pp. 153-167.

Camacho-Miñano, M. and del Campo, C. (2017), "The role of creativity in entrepreneurship: an empirical study on business undergraduates", Education + Training, Vol. 59 No. 7/8, pp. 672-688.

Che Embi, N.A., Jaiyeoba, H.B. and Yussof, S.A. (2019), "The effects of students' entrepreneurial characteristics on their propensity to become entrepreneurs in Malaysia", Education + Training, Vol. 61 No. 7/8, pp. 1020-1037. https://doi.org/10.1108/ET-112018-0229.

Chen, M. H. and Tseng, M. (2021), "Creative entrepreneurs' artistic creativity and entrepreneurial alertness: the guanxi network perspective", International Journal of Entrepreneurial Behavior \& Research.

Clarke, J. and Cornelissen, J. (2011). "Language, communication, and socially situated cognition in entrepreneurship." Academy of Management Review, Vol. 36 No. 4, pp. 776778. Danish, R. Q., Asghar, J., Ahmad, Z. and Ali, H. F. (2019), "Factors affecting "entrepreneurial culture": The mediating role of creativity. Journal of Innovation and Entrepreneurship", Vol. 8 No.1, pp. 1-12.

de Klerk, S. (2015), "The creative industries: an entrepreneurial bricolage perspective", Management Decision, Vol. 53 No. 4, pp. 828-842.

Dinis, A., do Paço, A., Ferreira, J., Raposo, M. and Gouveia Rodrigues, R. (2013), "Psychological characteristics and entrepreneurial intentions among secondary students", 
Education + Training, Vol. 55 No. 8/9, pp. 763-780. https://doi.org/10.1108/ET-06-20130085 .

Ehsanfar, S., Khosh Namak, S., and Vosoughi, L. (2021). A developing-country perspective on tourism students' entrepreneurial intention using trait approach and family tradition. Tourism Recreation Research, doi.org/10.1080/02508281.2021.1885800.

Esfandiar, K., Sharifi-Tehrani, M., Pratt, S., and Altinay, L. (2019), "Understanding entrepreneurial intention: A developed integrated structural model approach", Journal of Business Research, Vol. 94, pp. 172-182.

Farrukh, M., Alzubi, Y., Shahzad, I.A., Waheed, A. and Kanwal, N. (2018), "Entrepreneurial intentions: The role of personality traits in perspective of theory of planned behaviour", Asia Pacific Journal of Innovation and Entrepreneurship, Vol. 12 No. 3, pp. 399-414. https://doi.org/10.1108/APJIE-01-2018-0004.

Ferreira, J.J., Raposo, M.L., Gouveia Rodrigues, R., Dinis, A. and do Paço, A. (2012), "A model of entrepreneurial intention: An application of the psychological and behavioral approaches", Journal of Small Business and Enterprise Development, Vol. 19 No. 3, pp. 424-440. https://doi.org/10.1108/14626001211250144.

Fillis, I., \& Rentschler, R. (2010), "The role of creativity in entrepreneurship", Journal of Enterprising Culture, Vol 18 No. 1, pp. 49-81.

Fornell, C. and Larcker, D. (1981), "Evaluating structural equation models with unobservable variables and measurement error", Journal of Marketing Research, Vol. 18 No. 1, pp. 3950.

Galindo-Martín, M. A., Méndez-Picazo, M. T., and Castaño-Martínez, M. S. (2020), "The role of innovation and institutions in entrepreneurship and economic growth in two groups of countries", International Journal of Entrepreneurial Behavior \& Research, Vol. 26 No. 3, pp. 485-502.

Gartner, W. (1989), "Who is an entrepreneur? Is the wrong question", Entrepreneurship Theory and Practice, pp.47-68.

Gavetti, G., (2012), "PERSPECTIVE—Toward a behavioral theory of strategy”, Organization science, Vol. 23 No. 1, pp. 267-285.

Getz, D., \& Petersen, T. (2005), “Growth and profit-oriented entrepreneurship among family business owners in the tourism and hospitality industry", International Journal of Hospitality Management, Vol. 24 No. 2, pp. 219-242. 
Gielnik, M. M., Frese, M., Graf, J. M., \& Kampschulte, A. (2012), "Creativity in the opportunity identification process and the moderating effect of diversity of information", Journal of Business Venturing, Vol. 27 No. 5, pp. 559-576.

Gurel, E., Madanoglu, M. and Altinay, L. (2021), "Gender, risk-taking and entrepreneurial intentions: assessing the impact of higher education longitudinally", Education + Training, https://doi.org/10.1108/ET-08-2019-0190.

Gurel, E., Altinay, L., and Daniele, R. (2010), “Tourism students' entrepreneurial intention”, Annals of Tourism Research, Vol. 37 No. 3, pp. 646-669.

Gurol, Y., Atsan, N., (2006), "Entrepreneurial characteristics amongst university students: some insights for entrepreneurship education and training in Turkey", Education and Training Vol. 48 No. 1 pp. 25-38.

Haase, H., Lautenschläger, A. (2011), “The 'Teachability Dilemma' of entrepreneurship”, International Entrepreneurship Management Journal, Vol. 7, pp. 145-162

Hair Jr, J. F., Hult, G. T. M., Ringle, C., and Sarstedt, M. (2017), A primer on partial least squares structural equation modeling (PLS-SEM). Sage: Thousand Oaks.

Hamidi, D. Y., Wennberg, K., and Berglund, H. (2008), "Creativity in entrepreneurship education", Journal of Small Business and Enterprise Development, Vol.15 No. 2, pp. 304 320 .

Hu, R., Wang, L., Zhang, W., and Bin, P. (2018), "Creativity, Proactive Personality, and Entrepreneurial Intention: The Role of Entrepreneurial Alertness", Frontiers in psychology, Vol. 9, pp. 951. https://doi.org/10.3389/fpsyg.2018.00951.

Jackson, D. N. (1994). Jackson Personality Inventory - Revised Manual. Port Huron, MI: Sigma Assessment Systems, Inc.

Karami, M., \& Tang, J. (2019), "Entrepreneurial orientation and SME international performance: The mediating role of networking capability and experiential learning", International Small Business Journal, Vol. 37 No. 2, pp. 105-124.

Kaufman, J. C. (2012), "Counting the muses: Development of the Kaufman Domains of Creativity Scale (K-DOCS)", Psychology of Aesthetics, Creativity, and the Arts, Vol. No. 4, pp. 298-308.

Kautonen, T., Van Gelderen, M., and Fink, M. (2015), "Robustness of the theory of planned behavior in predicting entrepreneurial intention and actions", Entrepreneurship Theory and Practice, Vol. 39 No. 3, pp. 655-674. 
Kerr, S.P. Kerr, W. R., and Xu T. (2018), "Personality traits of entrepreneurs: A review of recent literature", Foundations and Trends ${ }^{\circledR}$ in Entrepreneurship, Vol. 14 No. 3, pp. 279356.

Ko, S., and Butler, J. E. (2007), "Creativity: A key link to entrepreneurial behavior. Business Horizons, Vol. 50 No. 5, pp. 365-372.

Koellinger, P. (2008), "Why are some entrepreneurs more innovative than others?" Small Business Economics, Vol. 31 No. 1, pp. 21-37.

Krueger, N. F., \& Brazeal, D. V. (1994), "Entrepreneurial Potential and Potential Entrepreneurs", Entrepreneurship Theory and Practice, Vol. 18 No. 3, pp. 91- 104.

Krueger, N. F., and Carsrud, A. L. (1993). "Entrepreneurial intention: Applying the theory of planned behaviour", Entrepreneurship and Regional Development, Vol. 5 No. 4, pp. 315330.

Krueger, N. F., Reilly, M. D., and Carsrud, A. L. (2000), "Competing models of entrepreneurial intention", Journal of Business Venturing, Vol. 15 No. 6, pp. 411-432.

Kumar, R., and Shukla, S. (2019), "Creativity, proactive personality and entrepreneurial intentions: examining the mediating role of entrepreneurial self-efficacy", Global Business Review, 0972150919844395.

Liñán, F., and Fayolle A., (2015), “A systematic literature review on entrepreneurial intention: Citation, thematic analyses, and research agenda", International Entrepreneurship and Management Journal, Vol. 11 No. 4, pp. 907-933.

Lopez-Nunez., M.I. Rubio-Valdehita, S., Aparicio-García, M.E. and Díaz-Ramiro, E.M. (2020), “Are entrepreneurs born or made? The influence of personality and Individual Difference" https://doi.org/10.1016/j.paid.2019.109699.

McMullen, J.S. and Shepherd D.A. (2006), "Entrepreneurial action and the role of uncertainty in the theory of the entrepreneur", Academy of Management Review, Vol. 31 No. 1, pp. 132 152.

Mitchell, R. K., Busenitz, L., Lant, T., McDougall, P. P., Morse, E. A. and Smith, J. B. (2002). "Toward a theory of entrepreneurial cognition: Rethinking the people side of entrepreneurship research." Entrepreneurship Theory and Practice, Vol. 27 No. 2, pp. 93 104.

Mitchell, R. K., Randolph-Seng, B. and Mitchell, J. R. (2011). "Socially situated cognition: Imagining new opportunities for entrepreneurship research." Academy of Management Review, Vo. 36 No. 4, pp. 774-776. 
Morris, M. H. and D. F. Kuratko (2002), Corporate Entrepreneurship. Mason, OH: SouthWestern College Publishers

Mueller, S.L., and Thomas, A.S., (2001), "Culture and entrepreneurial potential: a nine country study of locus of control and innovativeness", Journal of Business Venturing

Nasip, S., Amirul, S.R., Sondoh Jr, S.L. and Tanakinjal, G.H. (2017), "Psychological characteristics and entrepreneurial intention: A study among university students in North Borneo, Malaysia", Education + Training, Vol. 59 No. 7/8, pp. 825-840. https://doi.org/10.1108/ET-10-2015-0092.

Nielsen, S.L. and Stovang, P. (2015), "DesUni: university entrepreneurship education through design thinking”, Education + Training, Vol. 57 No. 8/9, pp. 977-991.

of Hospitality Management, Vol. 31 No. 2. pp. 489-499.

Niu, W. and Sternberg, R. J. (2001). "Cultural influences on artistic creativity and its evaluation." International Journal of Psychology, Vol. 36 No. 4, pp. 225-241.

Palmer, C., Niemand, T., Stöckmann, C., Kraus, S., \& Kailer, N. (2019). "The interplay of entrepreneurial orientation and psychological traits in explaining firm performance" Journal of Business Research, Vol. 94, pp. 183-194.

Peschl, H., Deng, C., and Larson, N. (2021), "Entrepreneurial thinking: A signature pedagogy for an uncertain 21 st century", The International Journal of Management Education, Vol.19 No.1, 100427.

Rauch, A., Wiklund, J., Lumpkin, G. T., \& Frese, M. (2009), “Entrepreneurial orientation and business performance: An assessment of past research and suggestions for the future", Entrepreneurship Theory and Practice, Vol. 33 No. 3, pp. 761-787.

Raza, A., Muffatto, M. and Saeed, S. (2018). "Cross-country differences in innovative entrepreneurial activity: An entrepreneurial cognitive view." Management Decision, Vol. 58 No. 7, pp. 1301-1329.

Ryan, R. M., and Deci, E. L. (2000), "Self-determination theory and the facilitation of intrinsic motivation, social development, and well-being”. American Psychologist, Vol. 55 No. 1, pp. 68-78.

Samydevan, V., Mohd Amin, M. R. B. and Piaralal, S. K. (2020), "Determinants of entrepreneurial intention among school students in Malaysia: An empirical study", Journal of Education for Business, pp. 1-7.

Schlaegel, C., \& Koenig, M. (2014), Determinants of entrepreneurial intent: A meta-analytic test and integration of competing models. Entrepreneurship Theory and Practice, Vol. 38, No. 2, pp. 291-332. 
Schumpeter, J. A. (2000). Entrepreneurship as innovation. Entrepreneurship: The social science view, pp. 51-75.

Shane, S., \& Nicolaou, N. (2015), "Creative personality, opportunity recognition and the tendency to start businesses: A study of their genetic predispositions", Journal of Business Venturing, Vol. 30 No. 3, pp. 407-419.

Shapero, A. \& Sokol, L. (1982), Social Dimensions of Entrepreneurship. In C. Kent, D. Sexton and K. Vespers (Eds), The Encyclopedia of Entrepreneurship.: Prentice-Hall: Englewood Cliffs, NJ 72-90.

Shepherd, D. A. and Krueger, N. F. (2002). "An intentions-based model of entrepreneurial teams' social cognition." Entrepreneurship Theory and Practice, Vol. 27 No. 2, pp. 167-185.

Shepherd, D. A., Williams, T. A., and Patzelt, H. (2015), “Thinking About Entrepreneurial Decision Making: Review and Research Agenda", Journal of Management, Vol. 41 No. 1, pp. 11-46.

Smith, E. R. and Semin, G. R. (2004). "Socially situated cognition: cognition in its social context." In M. P. Zanna (Ed.), Advances in experimental social psychology (Vol. 36, pp. 53-117). Cambridge, MA: Elsevier Academic Press.

Stauffer, D. (2016), "Personal innovativeness as a predictor of entrepreneurial value creation", International Journal of Innovation Science, Vol. 8 No. 1, pp. 4-26.

Sun, H., Lo, C.T., Liang, B. and Wong, Y.L.B. (2017), "The impact of entrepreneurial education on entrepreneurial intention of engineering students in Hong Kong", Management Decision, Vol. 55 No. 7, pp. 1371-1393. https://doi.org/10.1108/MD-06-2016-0392

Thomas, A.S., and Mueller, S.L., (2000), “A case for comparative entrepreneurship: assessing the relevance of culture", Journal of International Business Studies, Vol. 31 No. 2, pp. $287-$ 301.

Thomas, N., Randolph, A. and Marin, A. (2019). "A network view of entrepreneurial cognition in corporate entrepreneurship contexts: A socially situated approach." Management Decision, Vol. 58, No. 7, pp. 1331-1354.

Van Gelderen, M., Brand, M., Van Praag, M., Bodewes, W., Poutsma, E., \& Van Gils, A. (2008), "Explaining entrepreneurial intention by means of the theory of planned behaviour", Career Development International. Vol. 13 No. 6, pp. 538-559.

Van Gelderen, M., Kautonen, T., \& Fink, M. (2015), "From entrepreneurial intention to actions: Self-control and action-related doubt, fear, and aversion”, Journal of Business Venturing, Vol. 30 No. 5, pp. 655-673. 
Wales, W. J., Gupta, V. K., \& Mousa, F. (2013)., "Empirical research on entrepreneurial orientation: An assessment and suggestions for future research", International Small Business Journal, Vol. 31 No. 4, pp 357-383.

Wang, M.-Z., Chen, W., Zhang, C. and Deng, X.-L. (2017). "Personality types and scholarly creativity in undergraduate students: The mediating roles of creative styles." Personality and Individual Differences, Vol. 105, pp. 170-174.

Ward, T. B. (2004), "Cognition, creativity and entrepreneurship", Journal of Business Venturing, Vol 19, pp. 173-188.

Xu, X., Liu, W., and Pang, W. (2019), “Are emotionally intelligent people more creative? A meta-analysis of the emotional intelligence-creativity link", Sustainability, Vol. 11 No. 21, 6123.

Zampetakis, L. A., \& Moustakis, V. (2006), "Linking creativity with entrepreneurial intention: A structural approach", The International Entrepreneurship and Management Journal, Vol. 2 No. 3, pp. 413-428.

Zampetakis, L. A., Gotsi, M., Andriopoulos, C., and Moustakis, V. (2011), "Creativity and entrepreneurial intention in young people: Empirical insights from business school students", The International Journal of Entrepreneurship and Innovation, Vol. 12 No. 3, pp. 189-199.

Zampetakis, L. A., Kafetsios, K., Bouranta, N., Dewett, T., and Moustakis, V. S. (2009), “On the relationship between emotional intelligence and entrepreneurial attitudes and intentions", International Journal of Entrepreneurial Behaviour and Research, Vol 15 No. 6, pp. 595-618.

Zhang, Y., Zwiegelaar, J. B., and Kumar, V. (2020), “An investigation of performance of nascent manufacturing firms", Journal of Small Business Management, pp. 1-31.

Zhao X., Lynch, J., and Chen, Q. (2010), "Reconsidering Baron and Kenny: Myths and truths about mediation analysis”, Journal of Consumer Research, Vol 37 No 2, pp. 197-206.

Zhao, L., Davis, L., and Copeland, L. (2018), "Entrepreneurial intention: An exploratory study of fashion students", Journal of Enterprising Culture, Vol. 26 No1, pp. 27-50. 
Figures and Tables

Figure 1: Conceptual Model

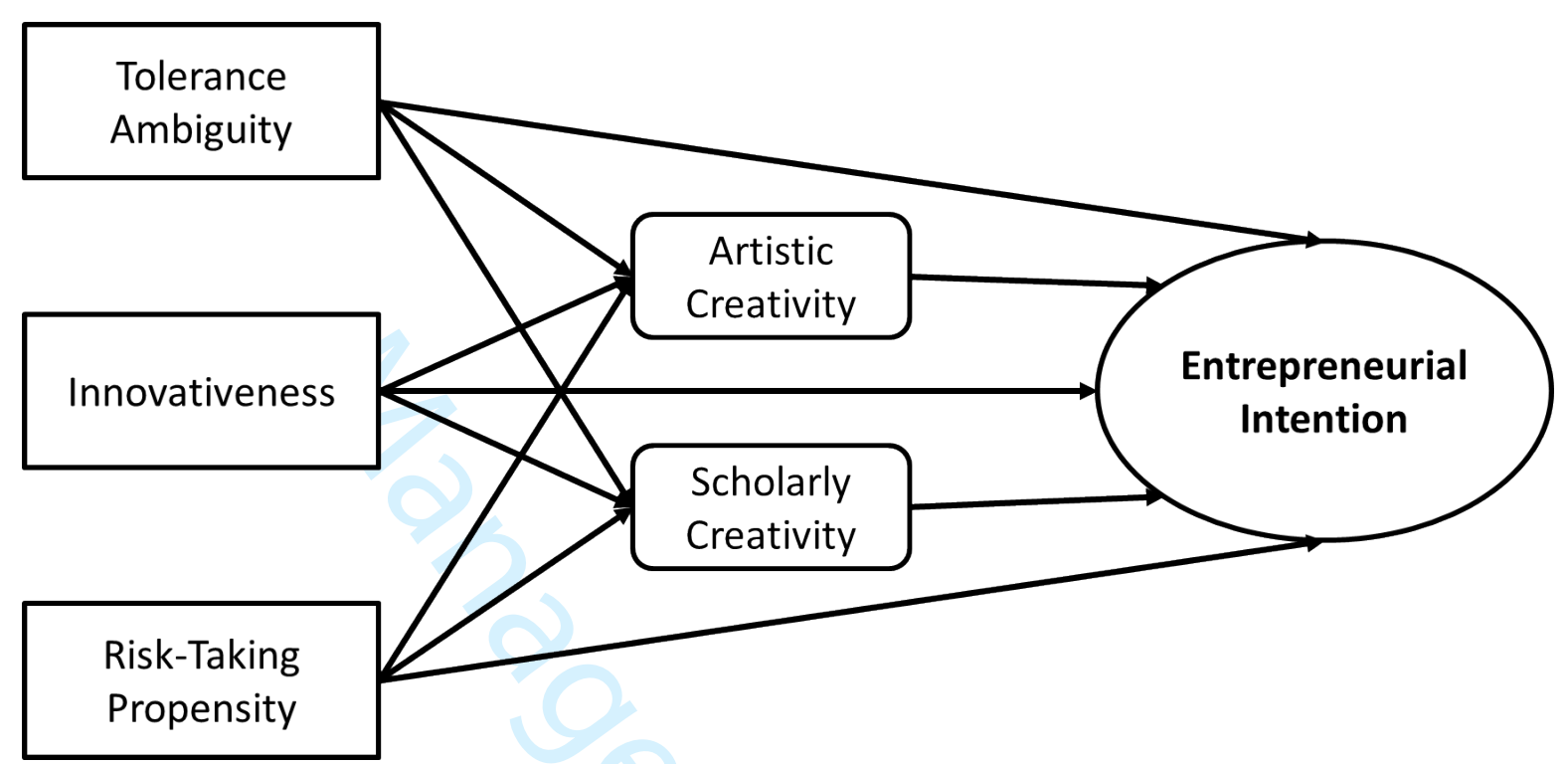

Figure 2: Final structural model and results of path analysis

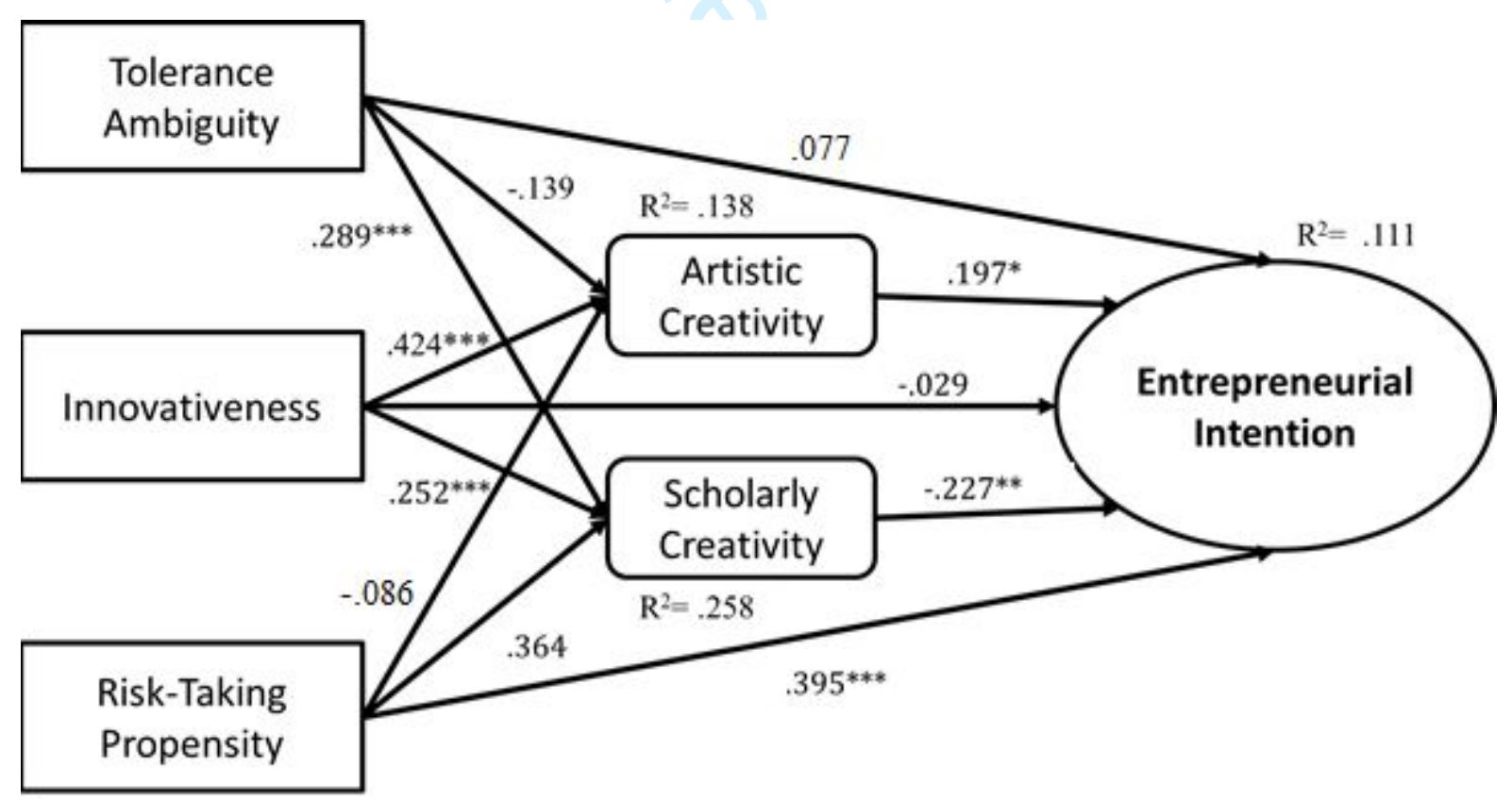


Table 1. Assessment of the measurement model.

$\lambda$

$\begin{array}{ccc}\alpha & \text { CR } & \text { AVE }\end{array}$

I enjoy working in uncertain situations.

$.617^{* * *}$

11 I often get irritated when unexpected events ruin my plans.

$.765^{* * *}$

12 The uncertainty surrounding my life prevents me from doing my best.

$712 * * *$

13 I enjoy the challenges of uncertain situations.

$.787^{* * *}$

$.642^{* *}$

17 People often ask me for help in creative activities.

$.832^{* * *}$

18 I prefer work that requires original thinking.

$.792^{* * *}$

19 I like to experiment with various ways of doing the same thing.

$.713^{* * *}$

21 I like a job which demands skill and practice rather than inventiveness.

$.702 * *$

22 I am not a very creative person (R).

$.736^{* * *}$

23 I obtain more satisfaction from mastering a skill than coming up with a new

$.588^{* * *}$ 24 idea.

\begin{tabular}{|c|c|c|c|c|}
\hline 25 Risk-taking propensity & $\sqrt{20}$ & .745 & .731 & .515 \\
\hline 27 Risk 1 & $.836^{* * *}$ & & & \\
\hline 28 Risk 2 & $.839^{* * *}$ & & & \\
\hline 29 Risk 3 & $.760^{* * *}$ & & & \\
\hline 30 Risk 4 & $.710^{* * *}$ & & & \\
\hline 31 Risk 5 & $.973^{* * *}$ & & & \\
\hline 33 Risk 6 & $.602^{* * *}$ & & & \\
\hline 34 Risk 7 & $.635^{* * *}$ & & & \\
\hline 35 Risk 8 & $.565^{* * *}$ & & & \\
\hline $\begin{array}{l}30 \text { Risk } 9 \\
37 \text { Risk } 10\end{array}$ & $.757^{* * *}$ & & & \\
\hline
\end{tabular}

$.818^{* * *}$

40 Drawing a picture of something I have never actually seen (like an alien)

$.719^{* * *}$

41 Sketching a person or object

45 Taking a well-composed photograph using an interesting angle or approach

57 Researching a topic using many different types of sources that may not be

58 readily apparent

59 Debating a controversial topic from my own perspective 
2

Responding to an issue in a context-appropriate way

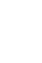

.


Table 2. Results of Heterotrait-Monotrait Ratio of Correlations (HTMT) for discriminant validity

\begin{tabular}{lccccc}
\hline Construct & $\mathbf{1}$ & $\mathbf{2}$ & $\mathbf{3}$ & $\mathbf{4}$ & $\mathbf{5}$ \\
\hline Innovativeness & - & & & & \\
Entrepreneurial intention & .166 & - & & & \\
Risk-taking propensity & .366 & .285 & - & & \\
Tolerance for ambiguity & .489 & .213 & .269 & - & \\
Artistic creativity performance & .427 & .141 & .261 & .166 & - \\
Scholarly creativity performance & .559 & .087 & .352 & .562 & .512 \\
& & & & & \\
\hline
\end{tabular}

Table 3. Results of path analysis

\begin{tabular}{lcccc}
\hline Path & Beta & T-Value & P Values & Decision \\
\hline $\begin{array}{l}\text { H1: Tolerance for ambiguity } \rightarrow \text { entrepreneurial } \\
\text { intention }\end{array}$ & .077 & .829 & .408 & Not supported \\
H2: Innovativeness $\rightarrow$ entrepreneurial intention & -.029 & .447 & .655 & Not supported \\
H3: Risk-taking propensity $\rightarrow$ entrepreneurial & $.395^{* * *}$ & 3.194 & .000 & Supported \\
intention & & & & \\
H4: Artistic creativity $\rightarrow$ entrepreneurial & $.197^{*}$ & 2.437 & .015 & Supported \\
intention \\
$\begin{array}{l}\text { H5: Scholarly creativity } \rightarrow \text { entrepreneurial } \\
\text { intention }\end{array}$
\end{tabular}

Table 4. Mediation results based on specific indirect effects

\begin{tabular}{|c|c|c|c|c|}
\hline Specific indirect effect & Beta & T-Value & P Values & Decision \\
\hline $\begin{array}{l}\text { H6a: Tolerance for ambiguity } \rightarrow \text { Artistic creativity } \rightarrow \\
\text { Entrepreneurial intention }\end{array}$ & -.011 & .680 & .497 & Not supported \\
\hline $\begin{array}{l}\text { H6b: Tolerance for ambiguity } \rightarrow \text { Scholarly creativity } \rightarrow \\
\text { Entrepreneurial intention }\end{array}$ & $.065^{*}$ & 2.361 & .041 & Supported \\
\hline $\begin{array}{l}\text { H7a: Innovativeness } \rightarrow \text { Artistic creativity } \rightarrow \\
\text { Entrepreneurial intention }\end{array}$ & .066 & 1.937 & .053 & Not supported \\
\hline $\begin{array}{l}\text { H7b: Innovativeness } \rightarrow \text { Scholarly creativity } \rightarrow \\
\text { Entrepreneurial intention }\end{array}$ & -.042 & 1.753 & .082 & Not supported \\
\hline $\begin{array}{l}\text { H8a: Risk-taking propensity } \rightarrow \text { Artistic creativity } \rightarrow \\
\text { Entrepreneurial intention }\end{array}$ & -.021 & .860 & .390 & Not supported \\
\hline $\begin{array}{l}\text { H8b: Risk-taking propensity } \rightarrow \text { Scholarly creativity } \rightarrow \\
\text { Entrepreneurial intention }\end{array}$ & .004 & .371 & .711 & Not supported \\
\hline
\end{tabular}

